\title{
DURATION IN HARRY POTTER AND THE DEATHLY HALLOWS
}

\author{
Wisnu Putra Wardhana \\ English Department of Unikom \\ wisnupwardhanaa@gmail.com
}

\begin{abstract}
This research is regarding narrative in Harry Potter and The Deathly Hallows. Narrative has many ways to develop the narrative. One of them is duration. There are five possibilities, which suggest themselves. They are summary, ellipsis, scene, stretch and pause. In each possibility, they have different use of time. Qualitative method and descriptive analysis are used to analyze the data. The data are taken from Harry Potter and The Deathly Hallows. The theory used in this research is from Seymour Chatman (1978). Summary occurs when the time is cut short in story-time, complemented with durative verb and adverb. Ellipsis is happened when the discourse in the story is stopped yet the story-time keeps on going, abridging the story-time to the period which is already determined. Scene happens when the story-time and discourse-time run together using dialogue and overt physical actions of relatively short duration. Stretch is happened when discourse-time runs longer than story-time, using imagination to cut short the story-time and enter the discourse time. Pause is occurred when the story-time stops completely and discourse-time takes over, describing the event or characters.
\end{abstract}

Keywords: Duration, narrative, story-time, discourse-time

\section{Abstrak}

Penelitian ini menjelaskan tentang narrative di Harry Potter and The Deathly Hallows. Narrative memiliki banyak cara untuk mengembangkan sebuah naratif. Salah satu caranya adalah dengan duration. Ada lima kemungkinan, yang menyatakan diri mereka sendiri. Kelimanya adalah summary, ellipsis, scene, stretch dan pause. Di tiap kemungkinan, mereka memiliki perbedaan dalam penggunaan waktu. Metode kualitatif dan analisis deskriptif digunakan untuk menganalisa data. Data-data untuk penelitian ini diambil dari Harry Potter and The Deathly Hallows. Teori yang digunakan adalah teori duration oleh Seymour Chatman (1978). Summary terjadi ketika waktu dipersingkat di story-time, dilengkapi dengan kata kerja dan keterangan yang duratif. Ellipsis terjadi ketika waktu penceritaan dihentikan namun story-time tetap berjalan, meringkas story- 
time ke waktu yang sudah ditentukan. Scene terjadi ketika story-time dan discourse-time berjalan bersamaan menggunakan dialog dan tindakan fisik yang jelas yang relatif pendek durasinya. Stretch terjadi ketika discourse-time berjalan lebih lama dari story-time, menggunakan imajinasi untuk menyingkat story-time dan memasukki discourse-time. Pause terjadi ketika story-time berhenti sepenuhnya dan discourse-time mengambil alih, mendeskripsikan peristiwa atau karakter-karakter.

Kata Kunci: Durasi, narrative, story-time, discourse-time

\section{INTRODUCTION}

Narrative is a discourse, oral or written, that narrates them Genette (1988; 13). In written literatures, the existence of narrative is much needed to tell the events or the story because narratives, for example, mainly direct the plot for in novels of movies. Either the plot is driven forward, backward or anywhere else, it is navigated by narrative. To which direction the plot moves is helped by time. Time can be said as the road to where this vehicle named narrative will go. This article discusses time, specifically duration. Chatman (1978: 68) states that duration measures the time of the story-events lasted, meaning that time becomes a deciding factor on a certain event. In Harry Potter and The Deathly Hallows, several cases of duration occur, which makes this research is initiated using the novel.

Due to the fact that time is imperative in determining how narrative moved, this research uses a theory regarding duration to examine how time is used to develop narrative.

\section{DATA SOURCE}

The primary source of this research is collected from novel Harry Potter and The Deathly Hallows by J.K. Rowling published in 2007. It tells a story about Harry Potter and his colleagues against Lord Voldemort and his Death Eaters. Harry had reached 17, a mature age in wizardry world, meaning he could do magic anywhere but would be tracked by Voldemort to be killed.

\section{METHOD}

Qualitative method and analytic descriptive is used for this research. It means that this research type method describes in the details specific situation. Sandelowski (2000) stated:

"Researchers conducting qualitative descriptive studies stay close to their data and to the surface of words and events. Qualitative descriptive designs typically are an eclectic but reasonable combination of sampling, and data collection, 
analysis, and re-presentation techniques. Qualitative descriptive study is the method of choice when straight descriptions of phenomena are desired".

It means that qualitative deals with how the data is presented after several research or experiments in reports. Qualitative analysis also deals directly with what the data provides from its sentence, components or anything attached to the data, make it easier to examine the data in qualitative analysis.

Furthermore, the data in the research is analyzed using analytic descriptive. As Sugiyono $(2010 ; 1)$ stated about the analytic descriptive:

"Metode Deskriptif adalah suatu metode yang berfungsi untuk mendeskripsikan atau memberi gambaran terhadap objek yang diteliti melalui data atau sampel yang telah terkumpul sebagaimana adanya tanpa melakukan analisis dan membuat kesimpulan yang berlaku untuk umum."

Considering Sugiyono's theory, the analytic descriptive takes the phenomena and gets the result from what is described from the research, which is why it is called descriptive.

\section{THEORETICAL REVIEW}

Duration is one of the ways to develop the narrative. It measures the time of the story-events lasted (Chatman, 1978:68). Duration has five possibilities, summary, ellipsis, scene, stretch and pause. The research's focus is to determine which duration develops the narrative into linear or nonlinear.

Summary is when the story-time runs longer than discourse-time, it depicts a summary of events in story-time; ellipsis occurs when the discourse is stopped yet the story-time continues; scene is happened when discourse-time and story-time are equal; it has two usual components, dialogue and overt physical action of relatively short duration, which do not take too much time to perform; stretch occurs when the discourse is longer than the story-time, and; pause happens when story-time stops though the discourse continues, as in descriptive passages. 


\section{FINDINGS AND DISCUSSIONS}

In Harry Potter and The Deathly Hallows, duration occurs several times in several parts of the novel.

For the first time since Harry had known him, Fred seemed to be lost for words.

(HPADH, 2007; 74)

Harry Potter, the protagonist of the novel, had a lot of friends. Two of them were the Weasleys twins, Fred and George Weasley. They were Ron Weasley's brothers. Fred and George were known as pranksters and always pulling out jokes. They even established a prank shop named Weasleys' Wizard Wheezes for those who like pranks. Harry and the twins had shared a long history of friendship and brotherly bond, so Harry knew them very well. When Fred was lost for words after George lost an ear in an ambush by enemies, Harry seemed to be completely surprised.

This part of the novel summarized the relationship between Harry and the twins since the first novel until the particular one in an event. Summary summarizes a group of events; in verbal narrative, this may entail some kind of durative verb or adverb, including iterative or repetitive form, or in some cases, temporal adverbial such as for or since (Chatman, 1978; 68). The novel did not tell the reader how they met or how they struck a friendship; it would be too long to retell their past story. It can be said that the author does not give too much attention to the detail of how Harry was implied to be surprised to see Fred lost a word before his brother or the reasons Fred lost a word before his brother. It implies that the reader had known the reasons of those two questions so the author just focuses on the recent matter.

Aside from summary, ellipsis also occured in this novel,

When he did not reply, she gripped his arm.

"Harry, he's taking over the Ministry and the newspapers and half the Wizarding world! Don't let him inside your head too!" (HPADH, 2007; 85)

This was the end of Chapter 5, where Harry told his friends, Ron and Hermione Granger that he had a vision about Voldemort, the main antagonist and Harry's nemesis, torturing Olivander, the wandmaker who made Harry's wand. The setting of this event was outside of the Burrows, the Weasley' residence, at night. Harry was thinking of running away so he would not endanger the lives of people he loved. Suddenly, he was struck by an excruciating pain when his mind 
was connected to the mind of Voldemort. Harry had this unique relationship with the Dark Lord Voldemort, where he could enter Voldemort's mind without him knowing. However, Harry did not intentionally do it. This incident ocassionally occurred when Voldemort was in rage or without any reasons.

This time, Harry unintentionally entered Voldemort's mind when Voldemort was furious to Olivander because he thought Olivander had lied to him about the way to kill Harry. When Harry got back from Voldemort's mind, his friends, Ron and Hermione, were next to him and he told that vision to them. That was the complete ending of Chapter 5 . However, the beginning of Chapter 6 was not the day after this event occurred. It was set days after the event in the end of Chapter 5.

The shock of losing Mad-Eye hung over the house in the days that followed; Harry kept expecting to see him stumping in through the back door like the other Order members, who passed in and out to relay news.

(HPADH, 2007; 86)

This was the beginning of Chapter 6. Notice the word which is bolded. It did not say that when Chapter 6 began, which was the aftermath of Harry's head got struck with pain. It only said that it was days after the event of Harry's pain. Ellipsis means that the discourse halts, though time continues to pass in the story. The discourse of what all of the characters in Harry Potter and The Deathly Hallows was halted, yet the story-time kept on going. If in the summary, the range of time which was traversed could be months or even, years, in ellipsis, only the discourse halted. The difference lies on how the time is acknowledged. Summary does not give much explanations of how the event ends like how it is told. Meanwhile, ellipsis gives implication that the event will end up like it is supposed to end because the characters have a steady pattern of what they will do. In this part of the novel, it did not tell what Harry and friends was doing during the days after his rescue attempt by the Order. It was implied that all of the characters did the same things that they always did before, emphasizing that what they had done in the past few days was not too important to be reported.

Aside from summary and ellipsis, scene was also occurred in the novel.

Bill walked over to the sideboard and pulled out a bottle of fire whisky and some glasses. 
"Here," he said, and with a wave of his wand he sent twelve full classes soaring through the room to each of them, holding the thirteenth aloft. "Mad-Eye,".

(HPADH, 2007; 79)

In this part, the Order was grieving the death of Alastor 'Mad-Eye' Moody, one of the members of the Order, who was struck by a Killing Curse in the face by their enemy, Death Eaters, Voldemort's minion. In this part of the novel, Bill Weasley, the eldest son of Mr and Mrs. Weasley, proposed a toast to honor MadEye's demise. Scene is developed by dialogue and overt physical actions of relatively short duration, the kind that do not take much longer to perform than to relate. Story and discourse here are of relatively equal duration. Here, Bill performed several actions which was short and effective, with a couple of dialogues that represent the situation of the event.

The last one is pause, which happens when Harry read an article regarding his old mentor, Albus Dumbledore.

\begin{abstract}
Harry finished reading but continued to gaze at the picture accompanying the obituary. Dumbledore was wearing his familiar, kindly smile, but as he peered over the top of his halfmoon spectacles, he gave the impression, even in newsprint, of betraying Harry, whose sadness mingled with a sense of humiliation.
\end{abstract}

(HPADH, 2007; 20)

In this part, Harry just finished read an article regarding his mentor. Pause occurs when story-time stops though the discourse continues, as in descriptive passages. Here, Harry was looking at the picture of Dumbledore who was looking back straight to him. Even though Harry did not speak directly to describe Dumbledore, the discourse took over the story by describing the kindly looking Dumbledore as Harry's gaze observe the picture.

\title{
CONCLUSION
}

In this novel, there are four appearances of duration, each of them represents linear narrative, because the events that were taken as data are in chronological order. It means that the events before and after are the cause and effect which lead to the data. 


\section{REFERENCES}

Bolewski, Christin. 2011. Nonlinear Narratives: Crossing Borders between Contemporary Film, Art and Digital Media Practice

Chatman, Seymour. 1978. Story and Discourse : Narrative Structure in Fiction And Film. New York. Cornell University Press.

Hosale, Mark-David. 2008. Nonlinear Media as Interactive Narrative. Santa Barbara. University of Carolina.

Phillips, W.H. 2005. Film: An Introduction. Bedford. Boston

Rowling, Joanne. 2007. Harry Potter and The Deathly Hallows. Bloomsbury. Bloomsbury Publishing.

Sandelowski, Margarette. 2000. "Whatever Happened to Qualitative Description". 15 November 2015. http://www.ncbi.nlm.nih.gov/pubmed/10940958

Tversky, Barbara, 2004. Narratives of Space, Time, and Life. 22 Juni 2016. psych.stanford.edu/ bt/space/papers/03_mila003.pdf 
